\title{
The Implementation of Teaching Material Integrated Religious Value
}

\author{
Hilda Handayani \\ Department of Chemistry Education, \\ Universitas Negeri Medan \\ Medan, Indonesia* coresponding \\ author: huruniin7@gmail.com
}

\author{
Ayi Darmana \\ Department of Chemistry Education, \\ Universitas Negeri Medan \\ Medan, Indonesia
}

\author{
Zainuddin Muchtar \\ Department of Chemistry Education, \\ Universitas Negeri Medan \\ Medan, Indonesia
}

\begin{abstract}
Making positive values in education is an effort for integrating religious values in the chemistry learning. The values of spiritual will not change the function of science because both of them can complete each other. Inserting these values are needed some appropriate approaches and method and be able to describe the science itself. This research was done to know learning process by chemistry teaching material integrated religious values. Instruments used questionnaire of spiritual value, multiple choice, and questionnaire of students response. The instrument of knowledge is validated by Chemistry Lecturer. The instrument of spiritual value consists of thanking and sincereness which had been validated. The analysis data used Independent sample t test on SPSS 20 for windows with its 0.05 significance. The first and second hypothesis are obtained 4.072 and 1.690 tcount. The third hypothesis is 0.471 in Pearson Correlation. Based on the analysis of knowledge, it is obtained $0.000<$ alpha $(0.05)$ a sig. score, while the analysis of spiritual value is obtained $0.046<$ alpha $(0.05)$ a sig. score. The Conclusions are the implementation of chemistry teaching materials integrated value can increase knowledge and spiritual value; there is a positive correlation between spiritual value and knowledge based on the Pearson correlation test minimum categorized as many as 0.471 ; students toward chemistry learning response to positive religious integrated with the average score as many as 0.804
\end{abstract}

Keywords - Teaching Materials, Integrated, Religious Value, Spiritual, Knowledge

\section{INTRODUCTION}

Education has an enormous influence in the formation of attitudes [1]. Integrating religious values can build a positive attitude of students. The values of spiritual will not change the function of science because both of them can complete each other. Inserting these values are needed some appropriate approaches and method and be able to describe the science itself [2]. Learning chemistry for beginners is an important starting point in developing aspects of knowledge and changing concept which is not scientific. The fundamental knowledge is the foundation of cognitive prior knowledge is required to understand the complex more [3]. Improving learning quality, including spiritual and knowledge competencies can be realized with innovative learning and teaching materials [4]. Teaching materials must incorporate the principles that allow changing learning for the better by paying attention to the curriculum used, contextuality, the interaction of learners, enabling students to be more focused, to encourage students to develop the skills of learning inside and outside the classroom, and presents a challenge that can be achieved students [5]. Empirical research on teaching material success in achieving the goals of learning, showed good results. Teaching materials generally consist of knowledge, skills and attitudes students need to learn in order to achieve the prescribed standard of competence. Based on the theoretical framework, relevant research and education needed in Indonesia, then implement the integrated value of religious teaching materials is expected to increase students' knowledge and spiritusal value.

\section{LITERATURE REVIEW}

\section{Knowledge}

Rahayu said that knowledge is understanding the main facts, concepts and theories explanation of scientific knowledge base [6]. Cognitive aspects/knowledge is divided into six levels with increasing order of complexity rises, namely: knowledge; understanding; application; analysis; (synthesis) and evaluation. Bloom divides knowledge into three sub-sections: Knowledge of specific things, knowledge of ways and means of dealing with specific issues, and knowledge of generalities and abstractions in a field [7].

\section{Teaching Materials}

Teaching materials give an important role in the learning process, learning materials capable of bringing the students in learning situations that allow to interpret, independent study and establish the concept that they receive in accordance with the learning experience [8]. In detail, the types of learning material consists of knowledge (facts, concepts, principles, procedures), skills and attitudes or values that students need to learn in order to achieve competency standards that have been established [9].

\section{Religion Value}

Religion gives compass and destination with a meaning that distinguishes humans from other creatures form. Rapid progress in the field of science and technology did not provide the ultimate cause of human happiness turned back to religious values [10].

Various empirical studies show correlation between spiritual values and religious person with the level of happiness and quality of life [11]. Tyler and Koenig argued that religious participation be the deciding factor in supporting 
health. Integration between spiritual values and health has long been a curriculum of medical schools in the United States [12]. The survey of medical school deans and faculty concluded that $90 \%$ of US medical schools have programs or content of religion, spirituality, and health., If the teacher is able to instill spiritual values in students, the students will be happy to learn and study, do not need to be forced to accept the lesson, because they realize everything that happens is for the sake of change for the better [13].

\section{The Implementation of Teaching Material Integrated Religious Value}

Teaching that blends science and religion were not weaken the contents of one of them, but rather mutually reinforcing both[14]. Presenting science in religion will improve the quality of faith through increased understanding of religion illogical and dogmatic [15].

Students interested in learning more in-depth chemistry for chemistry not just a collection of formulas and chemical equations that must be memorized and then forgotten after school, but the study of beauty and order oflaws divine in the universe [16].

\section{III.METHODOLOGY}

This research is a quasi-experimental Subjects in this study is a class XI Islamic Senior Highschool (MAN) Tebing Tinggi $2017 / 2018$ school year, and the object of this research is the implementation chemistry teaching material of Hydrocarbon and Petroleum integrated religious value. Design in this research can be seen in the following table:

TABLE 1 DESIGN RESEARCH

\begin{tabular}{|cccc|}
\hline Group & Pretest & Treatment & Posttest \\
\hline Experiment & $\mathrm{T} 1$ & $\mathrm{X} 1$ & $\mathrm{~T} 2$ \\
Control & $\mathrm{T} 1$ & $\mathrm{X} 2$ & $\mathrm{~T} 2$ \\
\hline
\end{tabular}

Description:

T1 : the initial test(pretest)

T2 : the final test (posttest)

X1 : learning with chemistry teaching material integrated religious values

X2 :learning to handle teaching materials student

Some of the variables in the research are independent variable are teaching materials and learning provided in both classes. The dependent variable increased knowledge and improved student spiritual values. The control variables in this study is the teaching material, namely hydrocarbons and petroleum, and teachers in both classes. Data collection instruments are detailed in the following table.

TABLE 2 INSTRUMEN DATA COLLECTORS

\begin{tabular}{|ccc|}
\hline Data & Instruments & Data Analysis \\
\hline Knowledge & multiple-choice & Independent $t$-test \\
\hline spiritual Value & Questionnaire & descriptively qualitative \\
\hline response of students & Questionnaire & Descriptive qualitative \\
\hline
\end{tabular}

Improved knowledge and spiritual values were analyzed by $\mathrm{N}$-gain further tested with independent sample t-test SPSS 20 in the second grade. The correlation between knowledge and spiritual values are calculated with Pearson correlation. Procedures for implementing this research can be seen in figure.

Fig 1 Research Procedure

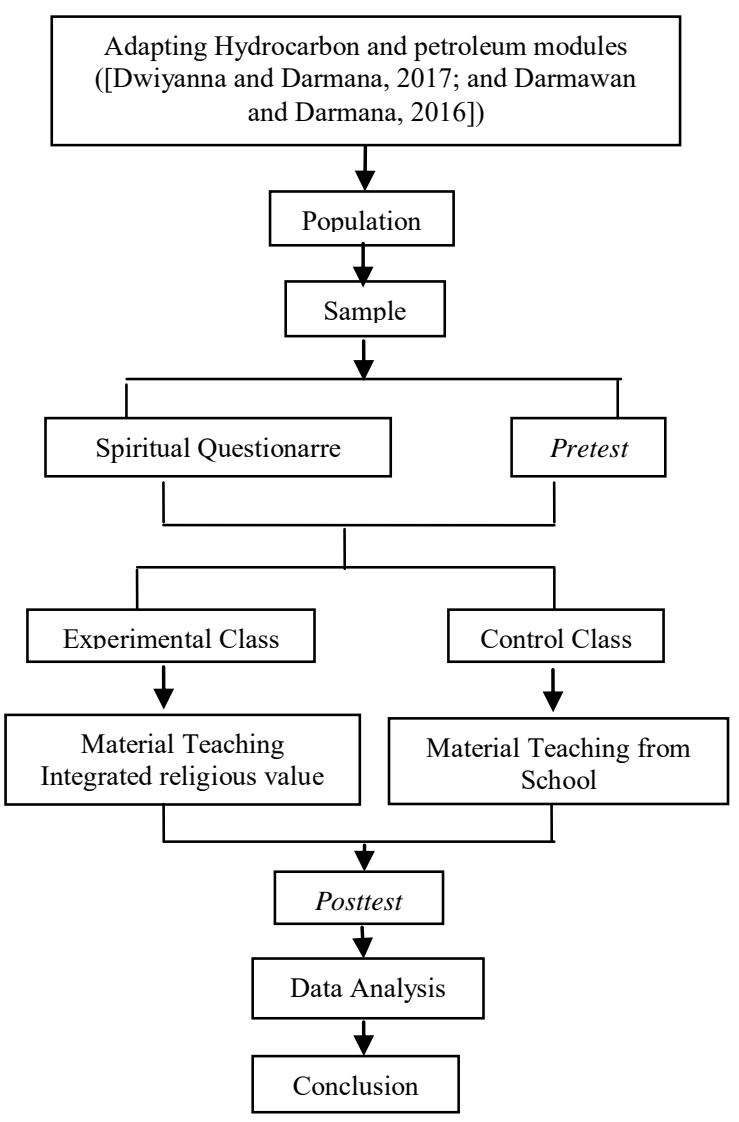

IV.RESULTS AND DISCUSSION

The results are the data of knowledge, spiritual and student response on teaching materials integrated learning with religious values. Results of research and discussion as follows:

\section{a. knowledge}

From the students' knowledge of data analysis derived from the value of knowledge of the instrument with five multiple choice answer options by students and adapted to the indicators to be achieved. There are three basic competencies outlined in the 25 item test of knowledge. Summary of the value of knowledge of students can be seen in the following table.

TABLE 3 VALUE KNOWLEDGE

\begin{tabular}{|cccc|}
\hline Class & pretest & posttest & Gain \\
\hline Experiment & 22.53 & 82.00 & 0.77 \\
\hline Control & 21.07 & 72.93 & 0.66 \\
\hline
\end{tabular}


Based on data value the pretest experiment and control class can be seen that the average value of the initial knowledge of students is still far from the minimum completeness criteria is 75 , that means students knowledge on the material of petroleum hydrocarbons and is still far from the expected.

Based on data from the value of knowledge of the experimental class and control class also can know the level of completeness of both classes can be seen from the results of the posttest presented in Figures 2 and 3 below:

\section{Percentage Knowledge Posttest of Experiment Classroom and Control}

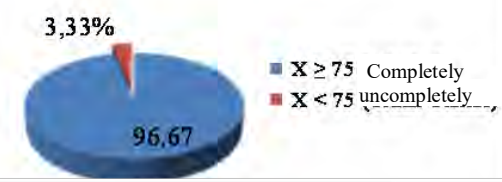

Fig. 2 Percentage Knowledge posttest Experimental class

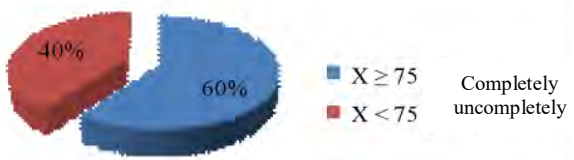

Fig. 3 percentage of Knowledge posttest Control Class

Data indicate that the increase in the highest knowledge obtained in the experimental class. Increased knowledge can be observed during the learning process. Students tend to have a great interest in learning and enthusiasm for teaching materials that are implemented. It is as stated Yuliawati (2013: 174) that the development of modules developed by the Islambased integration of science and Braille which connects science and Islam (Qur'an) invites students actively in learning.

\section{b. Spiritual Values}

From the analysis of the data, a preliminary picture of spiritual values student achievement obtained by recapitulate the spiritual value of the questionnaire instrument of positive and negative statements Likert scale. Statements that are positive category SS (very appropriate) were given the highest scores 5 and score gradually decreased to the lowest value 1 in the category of STS (very appropriate). Scoring the questionnaire can be seen in the following.

TABLE 4 SUMMARY OF THE AVERAGE VALUE OF THE SPIRITUAL WITH QUESTIONNAIRE

\begin{tabular}{|cccc|}
\hline Class & pretest & posttest & Gain \\
\hline Experiment & 3.21 & 3.42 & 0.48 \\
\hline Control & 3.16 & 3.34 & 0.22 \\
\hline
\end{tabular}

Based on data value the pretest (initial spiritual values) students experimental and control classes and averaging criteria specified in the previous chapter the achievement of spiritual values of both classes of both experimental and control classes in the enough category.

\section{Percentage Spiritual Value Posttest of Experiment}
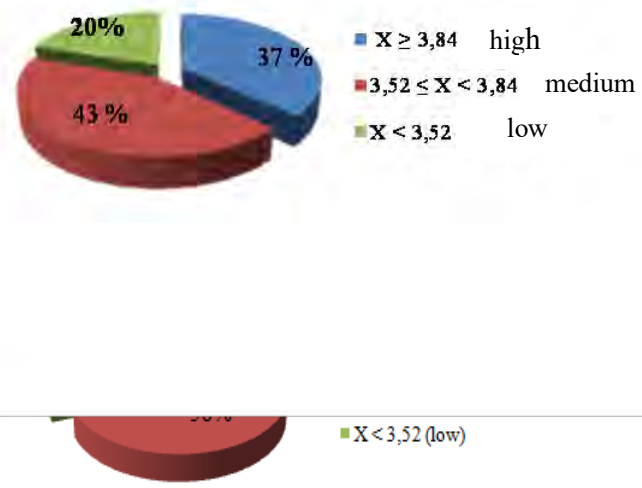

Fig. 5 Percentage Spiritual value posttest Control class

Based on data is concluded that the increase in the value of the experimental classes spiritual classes taught using chemistry teaching materials of hydrocarbon and Petroleum integrated religious value higher than the increase in value spiritual control classes are taught using high school chemistry textbook from schoolto students. With an average $\mathrm{N}$-gain experiment was 0.48 with category and class control was 0.22 with a lower category and the higher criteria percentage.

Increased knowledge can be observed during the learning process. Students tend to have a great interest in learning and enthusiasm for teaching materials that are implemented. Delivery of material on teaching materials containing illustrations and motivation and take examples closer to everyday life that actually has been described in the Qur'an, itself the enthusiastic students match the science with what is in the Qur'an. It also managed to cultivate a sense of gratitude to God and a sense of sincerity with the creation of this universe and everything in it also becomes important to utilize and record keeping for the benefit of mankind. Influence of teaching materials adapted here for integrated teaching materials spiritual values encourage students to form a positive attitude towards chemistry by realizing regularity and natural beauty as well as glorifying the greatness of God Almighty. Religious values can be included in high school chemistry textbook / MA in an attempt to enter a noble human character education [1]. Teaching materials fitted with religious elements and give positive energy to students. The description, example, Qur'an and hadith supporter, said the pearl of the scholars who are integrated in the teaching materials encourage students to think about the creations of Allah in the heavens, on earth and in man himself that encourages students to glorify and believe Creator, God.

Hydrocarbons and petroleum materials very closely with human life. So in chemistry teaching materials and Petroleum Hydrocarbons is an example of contextual problems and solutions in terms of chemistry taking into account the spiritual values. This material does not focus on numerical calculations but playing on a conceptual level so much contact with the realm of the philosophy of 
science. Opportunities to integrate Islamic values through very large philosophical approach in this matter (Asmara, 2016: 2).

\section{c. Response Experiment Class}

Students response using Chemsitry teaching material of Hydrocarbon and Petroleum integrated religious values measured by the questionnaire responses contain 23 item of positive and negative statements about the perceived student learning conditions.

TABLE.5.THE RESPONSE OF STUDENTS TO THE IMPLEMENTATION OF THE INTEGRATED VALUE OF RELIGIOUS TEACHING MATERIALS

\begin{tabular}{|lccc|}
\hline \multicolumn{1}{|c}{ Indicator } & Value & Category & $\mathbf{( \% )}$ \\
\hline attitude towards learning chemistry learners & 3.30 & $\begin{array}{c}\text { Very } \\
\text { Good }\end{array}$ & 82.5 \\
\hline $\begin{array}{l}\text { learners attitude towards learning chemistry } \\
\text { that is integrated with Islamic values }\end{array}$ & 3.01 & $\begin{array}{c}\text { Very } \\
\text { Good }\end{array}$ & 75.25 \\
\hline $\begin{array}{l}\text { submission of educators on chemistry learning } \\
\text { is integrated with Islamic values }\end{array}$ & 3.17 & $\begin{array}{l}\text { Very } \\
\text { Good }\end{array}$ & 79.25 \\
\hline $\begin{array}{l}\text { delivery Importance of Islamic values in the } \\
\text { learning of chemistry }\end{array}$ & 3.34 & $\begin{array}{l}\text { Very } \\
\text { Good }\end{array}$ & 83.5 \\
\hline $\begin{array}{l}\text { Effect of integrated chemical study of the } \\
\text { attitudes of learners }\end{array}$ & 3.26 & $\begin{array}{l}\text { Very } \\
\text { Good }\end{array}$ & 81.5 \\
\hline
\end{tabular}

under indicator table number 4 (the importance of Islamic values in teaching chemistry) obtained the highest score of 3.34; while the lowest score is on the indicator number 2 (the attitude of students towards learning chemistry that is integrated with Islamicvalues), this is understandable, because it had not previously been inserted Islamic values in the learning of science, in this case particularly chemical, there needs to be adjustment of rhythm learning between teachers and students for the purpose of learning can be implemented as planned, but the overall score obtained show category very good student responses.

\section{d. Prerequisites Test}

Normality test with SPSS 20. Kolmogorov-Smirnov Data is said to be normally distributed if assymp.sig (2-tailed)> 0.05 .

TABLE.6 TEST NORMALITY N-GAIN THE KNOWLEDGE AND SPIRITUAL VALUES

\begin{tabular}{|cccccc|}
\hline \multirow{2}{*}{ Class } & \multicolumn{2}{c}{ Kolmogorov Smirnov } & \multicolumn{2}{c|}{ Sig } & \multirow{2}{*}{ Description } \\
& G_K & G_SV & G_K & G_SV & \\
\hline Experiment & 0.613 & 1.037 & 0.847 & 0.233 & Normal \\
\hline Control & 0.948 & 0.383 & 0.330 & 0,999 & Normal \\
\hline
\end{tabular}

Test of homogeneity with Levene's test'. Is said to be homogeneous if assymp.sig (2-tailed)>0.05.

TABLE.7 TEST OF HOMOGENEITY N-GAIN THE KNOWLEDGE AND SPIRITUAL VALUES

\begin{tabular}{|ccccc|}
\hline \multirow{2}{*}{ Class } & \multirow{2}{c}{ Sig(2-tailed) } & & \\
& N_GainKnowledge & SV N_Gain & Sig. & Description \\
\hline $\begin{array}{c}\text { Experiment } \\
\text { Control }\end{array}$ & 0.533 & 8.771 & $\begin{array}{l}0.468 \\
0.004\end{array}$ & Homogeneous \\
\hline
\end{tabular}

\section{e. Hypothesis Test}

Hypothesis testing Independentsample t-test are summarized in the following table:

TABLE. 8 Results of Hypothesis Test Students gain KNOWLEDGE

\begin{tabular}{|ccccccc|}
\hline & Data & Sig. & $\boldsymbol{\alpha}$ &, & $\begin{array}{c}\mathbf{t}_{\text {able }} \\
(\mathrm{db}=58)\end{array}$ & Conclusion \\
\hline $\begin{array}{c}\text { Hypothesis- } \\
1\end{array}$ & $\begin{array}{c}\text { N-Gain } \\
\mathrm{K}\end{array}$ & 0.000 & 0.05 & 4.072 & 1.672 & $\mathrm{H}_{a}$ accepted \\
\hline
\end{tabular}

Second hypothesis is spiritual value in class that implemented the integrated teaching materials of religious values higher than students taught by material teaching high school chemistry/MA, by tested Independent sample t-test are summarized in the following table:

TABLE. 9 TEST RESULTS HYPOTHESIS GAIN SPIRITUAL VALUE

\begin{tabular}{|ccccccc|}
\hline & Data & Sig. & A & ${ }^{+}$ & $\begin{array}{c}\mathbf{t}_{\text {table }} \\
(\mathrm{db}=58)\end{array}$ & Conclusion \\
\hline $\begin{array}{c}\text { Hypothesis- } \\
2\end{array}$ & N-Gain SV & 0.046 & 0.05 & 1.690 & 1.672 & $\mathrm{H}_{\mathrm{a}}$ received \\
\hline
\end{tabular}

Third hypothesis that there is a correlation between the students' knowledge of spiritual values.

TABLE.10 TEST RESULTS CORRELATION GAIN KNOWLEDGE AND SPIRITUAL

\begin{tabular}{|lllll|}
\hline & aspect & K gain & Gain SV & Conclusions \\
\hline Pearson & Gain $\mathrm{K}$ & 1.000 & 0.471 & There is a correlation \\
& Gain SV & 0.471 & 1.000 & There is a correlation \\
\cline { 2 - 6 }
\end{tabular}

Djudin say when teaching science lessons and be integrated with other concepts will gain make teaching more meaningful for students [17]. Basically the educational goals will be achieved when religion and science combined. Science who rely on the power of logic will produce something useful or good when accompanied by a spiritual power that comes from religion. The combination of science and religion is a combination of the right concept for the understanding of nature [18].

\section{V.CONCLUSION}

Based on data processing and discussion of the results of research and discussion is concluded 1) To increase the knowledge of students who implemented an integrated teaching materials of religious values higher than students taught by high school chemistry teaching materials / MA handle students with value gain high category of 0,$77 ; 2$ ) Increasing the value of spiritual students who implemented an integrated teaching materials of religious values higher than students taught by high school chemistry teaching materials / MA with value gain high category by 0.48 ; 3 ) There is a positive correlation between the value of spiritual knowledge by Pearson correlation test medium category with a value of 0.471 ; and 4) The response of students towards learning integrated chemical positive religious values with an average score of $80.4 \%$. 


\section{REFERENCES}

[1] Saputro, A.N. Catur. 2011. Pengintegrasian Nilai-Nilai Relegius Dalam Buku Pelajaran Kimia SMA/MA Sebagai Metode Alternatif Membentuk Karakter Insan Mulia Pada Siswa. Seminar Nasional VIII Pendidikan Biologi: Biologi, Sains, Lingkungan, dan Pembelajarannya Menuju Pembangunan Karakter

[2] Darmana, A. 2012. Internalisasi Nilai Tauhid dalam Pembelajaran Sains. Jurnal Pendidikan Islam 17(1): 66-84

[3] Kirna, I. Made. Tanpa Tahun. Pembelajaran Pengembangan Pemahaman Konseptual Kimia Bagi Pebelajar Pemula. Seminar Nasional FMIPA Undiksha (166-174)

[4] Situmorang, M., M. Sitorus, W. Hutabarat, dan Z. Situmorang. 2015. The Development Of Innovative Chemistry Learning Material For Bilingual Senior High School Students In Indonesia. International Education Studie, Canadian Center of Science and Education 8: 10 (7285)

[5] Asyhari, Ardian, Widha Sunanro dan Sarwanto. 2014. Pengembangan Perangkat Pembelajaran Fisika Sma Berbasis Inkuiri Terbimbing Terintegrasi Pendidikan Karakter. Jurnal Inkuiri 3( I): 62-75

[6] Rahayu, Sri. 2017. Prosiding Seminar Nasional Kimia UNY 2017. Sinergi Penelian dan Pembelajaran untuk Mendukung Pengembangan Literasi Kimia pada Era Global. Ruang Seminar FMIPA UNY, 14 Oktober (1-16)

[7] Fathonah, Siti. 2005. Aplikasi Aspek Kognitif (Teori Bloom) dalam Pembuatan Soal Kimia. Kaunia, 1: 2 (152-167)

[8] Mursalin, Enggal. 2015. Pengembangan Bahan Ajar Bervisi SETS (Science, Environment, Technology And Society) Dan Berbasis Kewirausahaan Kimia (Chemoentrepreneurship) Kompetensi Terkait Hidrokarbon Dan Minyak Bumi. Majalah Ilmiah Pawiyatan 22 : 2 (113127)

[9] Fitriani, Fathma, Mahmud dan Ayi Darmana. 2016. Pengembangan dan Standarisasi Bahan Ajar Kimia Terintegrasi Nilai-Nilai Spiritual Untuk Kelas XI SMA/MA Semester 1 Berdasarkan Badan Standar Nasional Pendidikan. Jurnal Pendidikan Kimia VIII: 1 (12-18)
[10] Adawiah, Rabiatul. 2016. Integrasi Sains dan Agama dalam Pembelajaran Kurikulum PAI (Perspektif Islam dan Barat serta Implementasinya). Al-Banjari 15: 1 (99-124)

[11] Anganthi, N.R.N dan Zahrotul U. 2015. Pemaknaan Nilai-Nilai Spiritual Well Being Dalam Kehidupan Keluarga Muslim. The 2nd University Research Coloquium (215-226)

[12] VanderWeele, Tyler J. and Harold G. Koenig. 2017. A Course on Religion and Public Health at Harvard. AJPH Perspectives 107: 1 (4750)

[13] Agustian, Ary Ginanjar. 2004. Rahasia Sukses Membangun Kecerdasan Emosi dan Spiritual (ESQ) Berdasarkan 6 Rukun Iman dan 5 Rukun Islam. Jakarta: Penerbit Arga.

[14] Darmana, Ayi, Anna P., Sofyan S. dan Yayan S. 2013. Pandangan Siswa Terhadap Internalisasi Nilai Tauhid Melalui Materi Termokimia Serta Perlunya Dalam Materi Pelajaran IPA. Jurnal Penelitian Bidang Pendidikan 19: 2 (87-97)

[15] Okmarisa, H., A. Darmana dan R.D. Suyanti. 2016. Implementasi Bahan Ajar Kimia Terintegrasi Nilai Spiritual Dengan Model Pembelajaran Problem Based Learning (PBL) Berorientasi Kolaboratif Untuk Meningkatkan Hasil Belajar Siswa. Jurnal Pendidikan Kimia , 8: 2 (5863)

[16] Darmansyah. 2014. Teknik Penilaian Sikap Spritual dan Sosial dalam Pendidikan Karakter di Sekolah Dasar 08 Surau Gadang Nanggalo. Jurnal Al-Ta'lim, 21 (1): 10-17

[17] Djudin, Tomo. 2011. Menyisipkan Nilai-Nilai Agama Dalam Pembelajaran Sains: Upaya Alternatif Memagari Aqidah Siswa. Jurnal Khatulistiwa - Journal Of Islamic Studies 1(2): 151-160

[18] Hogan, M., J. 2009. On spirituality and Education. Thingking Skills and Creativity, 4 (138-143)

[19] Asmara, A.P.. 2016. Kajian Integrasi Nilai-Nilai Karakter Islami Dengan Kimia Dalam Materi Kimia Karbon. Jurnal Pendidikan Sains Universitas Muhammadiyah Semarang 4: 2 (1-11)K. Elissa, "Title of paper if known," unpublished. 